\title{
Listening to the Silences: A Teacher's First Year in Words and Music
}

\author{
Charles Vanover ${ }^{1}$ \\ University of South Florida St. Petersburg \\ vanover@mail.usf.edu
}

\begin{abstract}
Listening to the Silences is an ethnodrama - an example of verbatim theatre that evokes a teacher's first year in the Chicago Public Schools (CPS) based on the words voiced during a series of four interviews sessions conducted by the author. The protagonist, Indiana Ingelside, spent her first year in CPS in an African American school in one of Chicago's poorest neighborhoods. The show is intended to help the audience reflect on the beginning teacher's experiences of working in that setting. The script evokes the challenges of teaching within environments shaped by social policies that do not address, and frequently exacerbate, the poverty, racism, and other forms of injustice that shape the lives of children and families of color. The article begins with the complete playscript and then concludes with an afterword that describes what the author learned from developing and producing the show. Photos from the Philadelphia workshops are included.
\end{abstract}

Key words: beginning teachers, interviews, personal narratives, ethnodrama, teacher induction, Chicago Public Schools

\footnotetext{
${ }^{1}$ Biographical statement: Charles Vanover worked in the Chicago Public Schools for eight years before he received a fellowship to the University of Michigan's program in Educational Administration and Social Policy. Charles uses ethnodrama in his educational research; his ethnodramas have been performed more 40 times at various venues. Listening to the Silences is the first of Charles' four inquiry theatre plays to be published. Articles on the arts-based research practices used to develop these four shows are published by Qualitative Inquiry and in press from The Journal of Contemporary Ethnography. Current updates on Charles' plays and qualitative studies can be found at: https://www.facebook.com/InquiryTheatre
} 


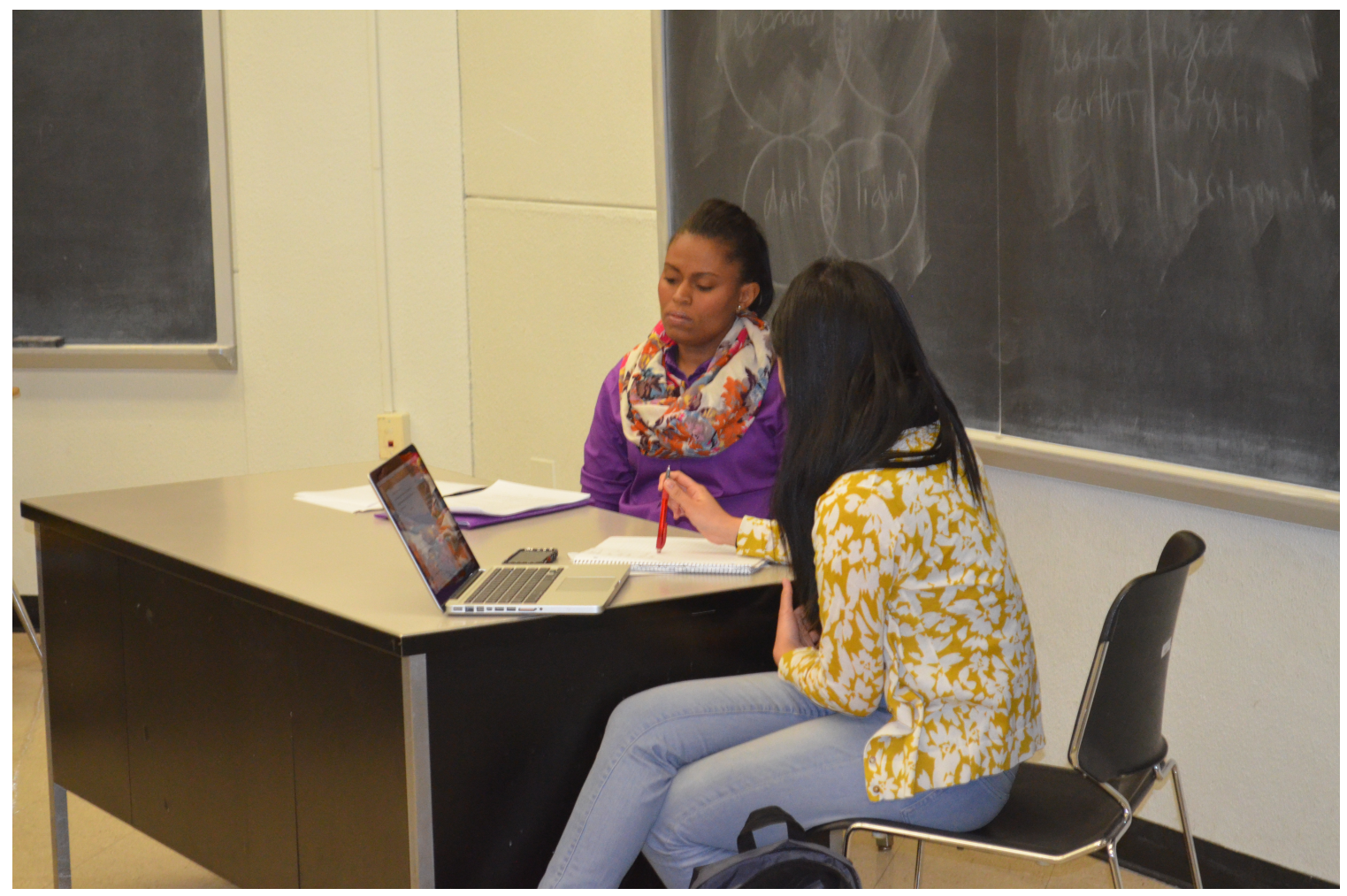

Photo 1: Kisha Barr and Jenna Lam performing at the Temple University preview performance of Listening to the Silences. Photo credit: Charles Vanover

Nothing is more frightening than the absence of an answer. Mikhail Bakhtin (1981, p. 111)

\section{Notes on the Script and Performance}

The playscript presented below was constructed from a verbatim transcription of an interview conducted by the author as part of a larger research study (see Vanover, 2016, in press). All names of people, schools, streets, and neighborhoods were changed to pseudonyms during the transcription process, and all pauses in the interview lasting longer than two seconds were timed and marked. Words have been cut from the transcript to dramatize these data (Saldaña, 2002), but no words have been added. Every word spoken in the script is presented in the ethnodrama in the original order it was voiced.

Listening to the Silences is intended to support audience discussion about first year teachers' experiences in schools that serve low income and minority students; brief suggestions for guiding this dialogue may be found in the discussion which follows the script. Following the principles of inquiry theatre, future productions may cut words from the script and may make changes to the music and the staging, but no words may be added to such future works, nor may these performances change the order of the dialogue. 

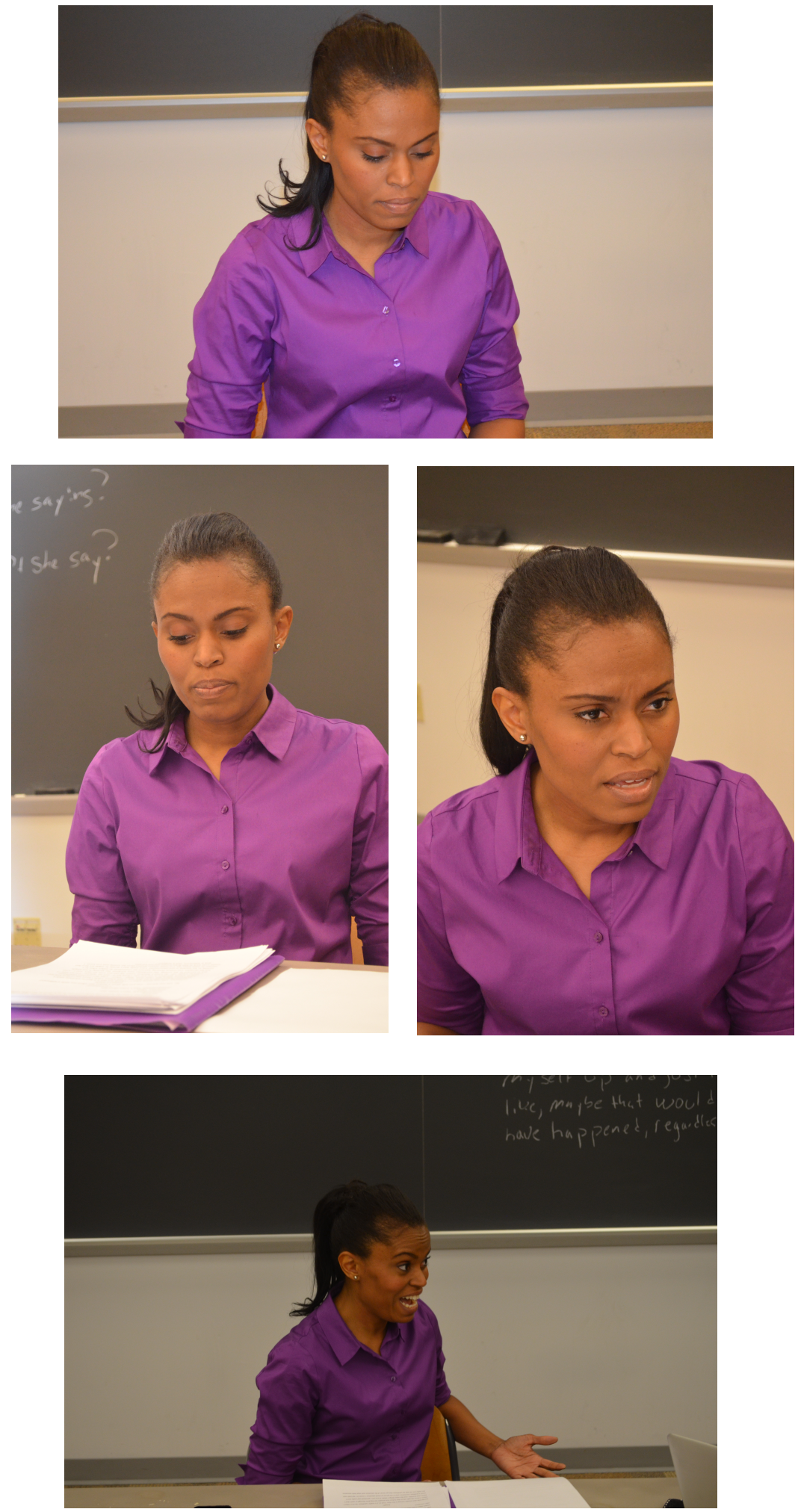

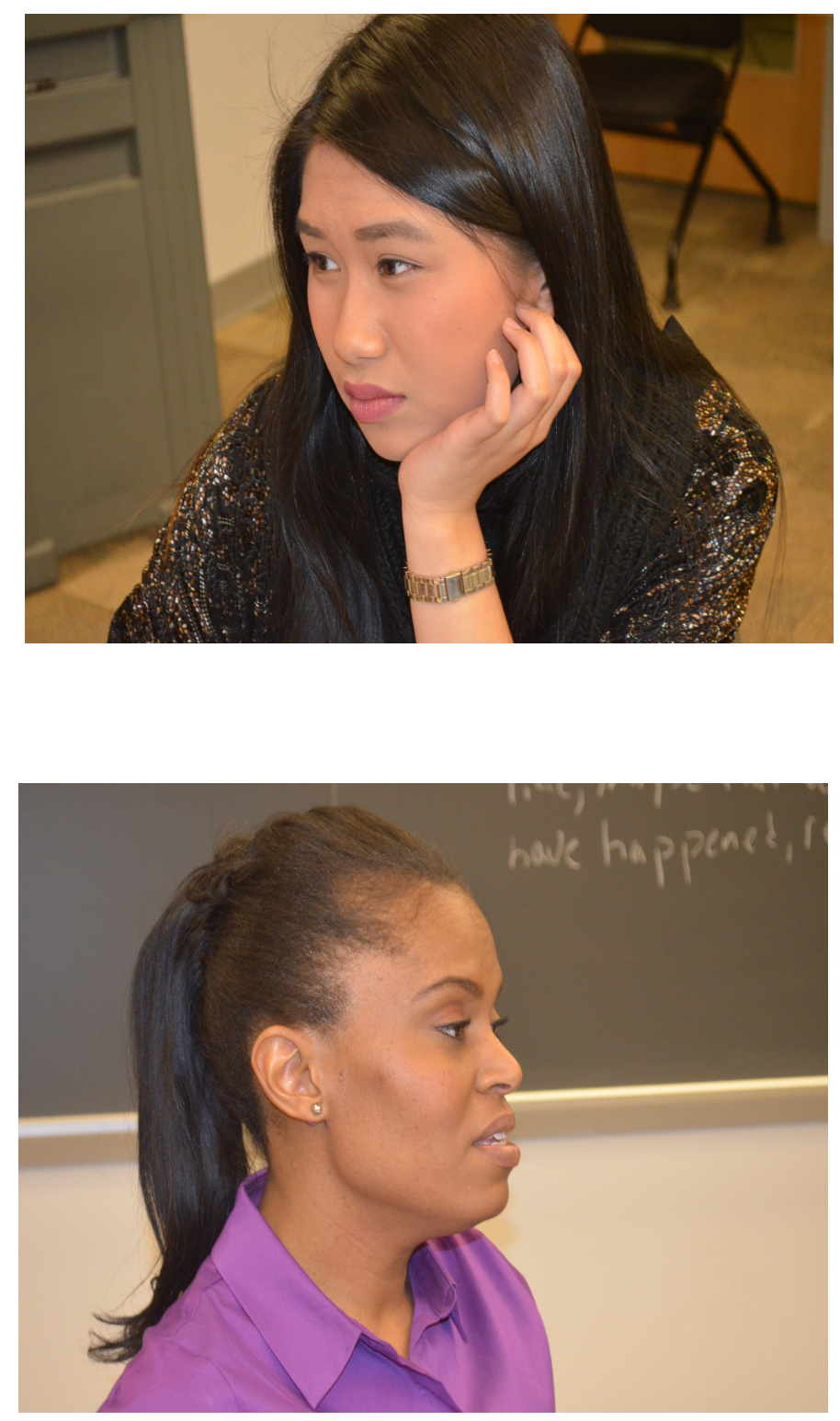

Photos 2, 3, 4, 5, 6 \& $7^{2}$ : Kisha Barr as Indiana Ingleside and Jenna Lam as The Interviewer. Photo credit: Charles Vanover

\footnotetext{
${ }^{2}$ Photos in this series come from the February $28^{\text {th }}$ performance for the Ethnography in Education Research Forum.
} 


\section{The Ethnodrama}

\section{Cast in Order of Appearance ${ }^{3}$.}

THE FACILITATORS are the producers of the piece. At a university or school district performance, THE FACILITATORS might be faculty members with research interests in teacher induction and retention; at a performance put up by a community group, THE FACILITATORS might be neighborhood leaders with an interest in improving local schools. THE FACILITATORS hand out programs to audience members before the piece begins, and they guide the discussion that concludes the work ${ }^{4}$.

THE MUSICIANS: Different arrangements of Arvo Pärt's Fratres are played throughout the show by local musicians. School of music students might play in a performance hosted by a university. High school students might play in a performance hosted by a school district. Performances without live musicians might use conductor Rudolf Werthen's Telarc recording of Pärt's Fratres.

THE INTERVIEWER is a graduate student working on his/her dissertation. $\mathrm{He} / \mathrm{she}$ has a bag/backpack that holds tape recorders, informed consent forms, and other interview paraphernalia.

INDIANA INGLESIDE is a first year teacher in the Chicago Public Schools $(\mathrm{CPS})^{5}$. Indiana is of English and Scandinavian ancestry and grew up in northern Indiana, near the Michigan and Ohio border. Indiana was a communications major in college and worked in public television at a large public university after receiving her BA. Indiana moved to Chicago and got her master's degree as part of a CPS program that paid teacher education students to work as apprentices to master teachers. THE INTERVIEWER said these words about Indiana as he

\footnotetext{
${ }^{3}$ Two sets of preview performances were staged. The first two performances were put up on February $25^{\text {th }}$, 2015, at Temple University, and on February $28^{\text {th }}, 2015$, at the University of Pennsylvania. The Penn performance was staged as part of the peer reviewed program of the Ethnography in Education Research Forum. The show was written and directed by Charles Vanover. Performers were Kisha Barr as INDIANA and Jenna Lam as THE INTERVIEWER. Co-chairs of the session were Andrew Babson and Sarah Hobson. The session respondent was K. Nicola Williams. The second series of performances were staged by The Studio @ 620 in Saint Petersburg, Florida, as part of The Studio's social justice series. Lisa Powers Tricomi played INDIANA in these performances and The Studio's artistic director, Bob Devin Jones, directed the performance and played the part of THE INTERVIEWER. All of these performances were staged without live music and photos of these events reflect this simple staging.

${ }^{4}$ These programs contain excerpts from the script and are intended to support the post show discussion. See Vanover (2013b, 2013c) for examples of different programs.

${ }^{5}$ The individual upon whom the character of Indiana is based was interviewed by the author for his doctoral dissertation research.
} 
spoke into his digital recorder after her interview: "Very nervous in the beginning, shy. She would look down. Very beautiful woman, blond, beautiful, blue eyes, just really seemed kind, caring."

Setting. The door to the performance space is closed. THE FACILITATORS greet audience members in the lobby and pass out programs that contain excerpts from the script and the performance's central questions. THE FACILITATORS use these interactions to talk with audience members about the show and to set the mood for the production. THE INTERVIEWER and INDIANA stand with the other audience members, but they do not draw attention to themselves, beyond the fact that THE INTERVIEWER carries a backpack that contains the documents and equipment he/she will use to conduct the interview.

The doors open. The first group of audience members takes their seat. At center of the stage sits a table with two chairs. A chalkboard or a white board is placed behind the table and frames the interview space. THE MUSICIANS sit on either side of the center table. The room is set up to support interaction and, if possible, chairs are organized around tables to support discussion between audience members at the conclusion of the show.

THE FACILITATORS walk audience members to their seats and ask them to read the program quietly. After the first wave of audience members are seated, THE MUSCIANS play Arvo Pärt's Fratres (For strings and percussion) ${ }^{6}$. THE INTERVIEWER quietly walks onstage a couple of minutes after the THE MUSICIANS begin to play; THE INTERVIEWER sits at the center table with his or her back to the audience and prepares for the interview by placing IRB forms, a cassette recorder, a digital recorder, and interview guide on the table to set up for the interview.

The musical piece ends and THE MUSICIANS sit silently; the last audience members are walked to their seats.

A minute of silence;

\footnotetext{
${ }^{6}$ The different versions of Fratres used in this ethnodrama are taken from Pärt (1977). The titles used on that CD are the titles used in this script. See Young Muscians Foundation (2010) for a video of Pärt's Fratres for Solo Violin and Strings that communicates the look of the stage and the sound of the music.
} 
INDIANA leaves the audience, walks on stage, and greets THE INTERVIEWER. She sits at the center table facing the audience. The two talk silently as INDIANA signs an IRB form and looks over the interview guide.

INTERVIEWER: Testing. Testing. Testing.

THE INTERVIEWER hits the play button on the recorder. The voice from the recorder says: Testing. Testing. Testing.

THE INTERVIEWER puts the recorder in position and hits record;

Music up; Pärt, "Fratres, (For 8 or 12 cellos)".

The music begins softly at first and slowly increases in volume as the interview progresses. Throughout the piece, THE MUSICIANS respond to the dialogue shared between the two actors; actors and musicians work as an ensemble.

INDIANA: I read the homework assignment and thought about it, but I didn't prepare anything.

INTERVIEWER: That's totally fine.

INDIANA: Okay.

INTERVIEWER: Don't worry about that (5 second pause). So, can you tell mecan you talk about a student where you made a difference?

INDIANA (Laughs): Um, you know, I don't—I kinda feel that it is hard to tell if you made a difference because this is my first year at this school. I didn't know any of these kids and I don't know where they came from. What-where-what their previous experiences were in school. But there is one kid who I think is-just my opinion-l'm not sure-l could be totally off-he's just a fabulous writer. He can just write for days. And I-I just got so excited by his writing. His mechanics were not great. His spelling is just alright, but his thoughts and critical thinking and just the connections he makes when he's writing to his reading is just phenomenal. I just really had a feeling he might not have had success in other areas. So, I'm really always praised about his writing and, you know, I would write back to him in his journal and just tell him, "This is fabulous. This is brilliant." And I-just I-I 
think it made a difference to him and just his—his—his esteem a little bit. I know that he really fed off it because he would really write more. And by the end of the year-I only required them to write a reading response journal back to me once a week, but he was writing every day. I mean he would read and then he would have something to writing about every day. So-that made me happy. It's those little things (Laughs) that you just really got to celebrate sometimes. So-1throughout the year I photocopied their journal responses and I put them on the overhead and then we talked about what did the student do well. What did-what could the student do better. And so it was a learning experience for everyone. And, you know, just trying to really stress what they did that was positive. I really feel like that really made a difference in his life. And just yesterday, I bought him a book about-it was called The Writer's Notebook-and two journals, because I know that over the summer he's going to be writing a lot. He'll fill up two journals no problem. So, I gave that to him yesterday because I felt that he would actually use it. He will spend the time to do that over the summer. So...

\section{3 second pause;}

INTERVIEWER: That's great. Could you talk about your writing teaching since you mentioned that. Just talk about, you know, how do you do? How do you teach writing in your classroom?

INDIANA: Well, I structured my writing in a writing workshop where we go through, um, brain storming, you know, finding a topic, brainstorming, first draft, edits. You know, revising and-It-I need to improve on it for next year because there were some things - I didn't get to conference enough with students. It just seemed like it was just one of me and so many questions. (She laughs) So, I need to work - I need to find a better way. But actually towards the end of the year what I was doing was-when they were working on their writing pieces I would do half-I would split the class and half of them would be doing their independent reading and the other half would be writing. So then, if kids did need help, I was only dealing with, you know, 15 instead of 30 . So, that was, you know, that worked better for me and l'll probably start out that way next year. (She laughs) It's just a lot to get done. And we did share some of our pieces when we were finished and-but I need to do a better job of posting them and letting the kids type them out and make 'em look nice.

INTERVIEWER: You used the computer? 
INDIANA: We use laptops at our school. Yeah, we have quite a few, actually. We are pretty lucky. But we don't have a printer and so I have to email them all to myself and then print them out at home.

\section{4 second pause;}

INTERVIEWER: Okay, could you talk about um like a specific unit-this is one of our questions-where you thought that you really made a difference? Or that you were really proud of? Or that you really enjoyed?

\section{0 second pause;}

INDIANA: We did a science unit on plants and I allowed them to plant peas. We planted peas in the classroom. Which was fun. (She laughs) Yeah, they each got their own cup and their own pea and they were really proud of it. And I-I feltfelt like a lot of them had never planted something and watched it grows and took care of it before. And also we-not only was it learning about plants, but it was an exercise in observation. So, we would record our observations of the plant growing every couple of days. It was just-it was fun. I think that they got excited a little bit about plants and the environment and then something that's theirs and that's living. So, it was good. I'll probably do it again next year.

INTERVIEWER: Okay, great. Could you talk about moments during the year when you felt that you had really learned something new about your teaching or your students?

INDIANA: Everyday. (Laughs, followed by 10 second pause) I learned so much from the kids this year. I-It's hard to pick one, but, a lot of what I learned is just how (5 second pause) like how kids react to their environment and how they react to how people treat them and (6 second pause) before this year I just-I had-I did a year at lona Elementary School as part of my Master's program and then this was my first year with my own classroom. I had never worked with kids this closely (Laughs) as this year. So, it was a really a learning experience on a lot of levels. Just (4 second pause). It just-it-the kids bring a lot into the classroom. And because we are a neighborhood school they all live within blocks of each other. They all know each other way too well. They live across the street from each other. They know each other's families. And-and-I think it just 
makes it a little bit worse, because they are just too intimate. (4 second pause. Speaks slowly) As far as the teaching part (4 second pause). I guess I have been really reflective on (4 second pause). The scaffolding, you know, building up to what they really need to know to successfully complete projects; (8 second pause. Speaks quickly) I think that there was just so many things. Like, for instance, I never thought that each kid having a book all year would be an issue. But some kids take their books home and never bring them back. Some kids leave them, you know, wherever. Some kids when they come to school and don't have a book they will take a book from someone else's desk and then that person-I mean, it was like-that was something I (Snaps her fingers) I never thought it—it just never crossed my mind. I mean, there's just—-things are (Laughs) crazy like that. And then there's things, like in my school, there's really hard to ask kids to bring supplies because some of these kids are not, I mean, they really don't know where their last meal is coming from. So, it's like, I felt like all year I was caught between, you know, trying to make them responsible for coming to school prepared as a far as like paper and pencils and stuff, but, at the same time, I don't know if they have eaten in the last twenty four hours. So, you know, I always, and I spent so much money just on paper and pencils all year. I didn't have the heart to be, like, you know, "What? You don't have a pencil?" (Laughs). So I-I-maybe that's not a learning experience 'cause I still haven't figured out what I'm going to do next year.

\section{Music fades out;}

INTERVIEWER: Anything else. Any other things that you thought you really learned?

\section{6 second pause;}

INDIANA: Yeah, I am sure there are, but I (6 second pause) I mean that I learned something every day. It was incredible experience. (Laughs)

INTERVIEWER: What was that like?

INDIANA: It was really good. I feel that I am a more knowledgeable person for having gone through this experience. Not that I don't feel that I was naïve before. I mean, in my other career, I was always, well, I have always been interested in education and I was kind of in education before, as I worked for University of Indiana extension in public television. So, it was connected to education and I was always reading about, you know, educational policy and what was going on in trends and just always very excited about it, so the decision to become a teacher came pretty naturally. But, so, even though $1-1-1-1-1-1-1$ had read about all this stuff to actually be in it and doing it is like so-(Laughs). It's just so, 
you know, in your face and real. So (8 second pause) I mean, I learned a lot of the issues with the system that are (4 second pause). You know, really troubling. For instance, before I was a teacher, I would read about these kids who would graduate from high school and couldn't read and I was like "How in the world does that happen?" Well, after this year, I can see that kids get passed on because you can't hold the kid in their grade forever. Because I had-in $5^{\text {th }}$ grade-I had like four or five thirteen year olds. A 13-year-old kid is in a very different place socially than a 10-year-old. And it creates chaos in the class to have these 13-year-old kids torturing the little 10 year olds who, you know (Laughs) are the kids that actually belong in the class. And so, it's really a problem. So it's, I don't know, I never thought about that before, but actually having gone through it, and I don't know, just horrible. And the other thing, I think, if you are a good kid and really don't cause a problem, you know, you're not given as much attention. I mean it's the kids who are really act out and are problems that get most of the attention and what little resources there are. So, I mean, for instance I had at least 5 kids that I did not feel should be promoted to the $6^{\text {th }}$ grade and when I went to make my case because why they should not be promoted I was only able to hold one of them back. Because of age. Mostly, because of age. Some kids didn't do any work all year, but scored okay on the lowa test. So, you know, if they if they can score a 40 percentile on the lowa test there is no reason to hold them back. But then that sends just a horrible message to those kids that saw that kid do nothing all year. So, that's-l learned that there's a lot of problems. How we do things. And I'm not sure. I'm not sure how to-how it gets fixed. That's probably part of the reform piece that you are trying to figure out.

INTERVIEWER (Softly): Well, I don't know about that. (Louder) Talk about your own classes. What would you do, specifically, with like the 13-year-olds in your class? What would you do for them?

\section{4 second pause;}

Music up; Pärt; "Fratres, (for violin, strings, and percussion)"; Music plays softly and then grows in intensity and volume;

INTERVIEWER: How would you manage that?

INDIANA: Well, I had two at the beginning of the year that eventually got taken out 'cause they were just really distracting other kids. And I got them half-like I got them in October because we had to close down one of the classes. All the kids from the $3^{\text {rd }} / 5^{\text {th }}$ grade class got dispersed into the two existing $5^{\text {th }}$ grade classes. And, a lot of times, they didn't-they didn't come. They didn't even come to school, but when they were there (4 second pause) I would just-just, you 
know (4 second pause). Try anything to keep them (5 second pause). Occupied, basically, you know (5 second pause). Ummmm (5 second pause). You know, a little extra help, probably, you know, I would probably stand by them more and make sure that they were following. Of course, these were the kids who need the most help with the fundamental basic things. And when you have 30 kids in your class it's really to give them what they need. And, I couldn't, actually. I didn't. I didn't give them what they needed. (4 second pause. She laughs)

\section{INTERVIEWER (Speaking very softly): That's okay.}

\section{8 second pause;}

INDIANA: And there is not any (8 second pause. Sadness in her voice; she is almost in tears, but she never actually cries) I thought that there would be people to come in and take them out and help them, but there's not. There was never anybody who came in, like, and took out the kids who didn't know their multiplication tables yet which I thought there would be. Kids who just needed just really basic help in reading. There's kids in the $5^{\text {th }}$ grade who didn't know like $1^{\text {st }}$ grade sight words. So, sometimes, when everyone else is independent reading, you know, I would just take-luckily for some reason I bought the sightword flashcards, probably not even thinking that they would need them, but I did. And so, I would just go through sight-words and have them read really basic books to me. Or-and we would like pair up and I would read a page and they would read a page. But I, you know, I didn't do a good job differentiating instruction as much as I would like to and (4 second pause. The sadness begins to leave her voice). So, I gotta-I have to do better with that for next year too. But yeah (Laughs; recovers). So, then half way through the year those kids they got placed in other classes because of their age. And then, I had another 13 year old all year who basically was alright. I mean he assimilated himself pretty well. So he wasn't—he wasn't a real big problem, but, actually, he had this 13-year-old attitude, like, you know, everything I said he just said the opposite (Laughs). So, in like April or May, I think it was like April, he was-I can't remember what he said. I said something to the class and then he said something just totally the opposite and I said "You know what? You can disagree with me, but I still love you anyway." In front of the whole class. (INTERVIEWER laughs) And then everybody was, like, "OOOOO!" And then, he kind of just chilled out. Because how can you, like, you know, be mean to somebody who just told you that they loved you? You know, and so, then I didn't have a problem with him for a really long time. (Both laugh) He just kind of, you know, he just kind of smiled and got over it, but (4 second pause). It's kind of always been my philosophy to just kind of kill them with kindness. You just have to, you know, I think, be very strict and firm and mean what you say but not in a yelling type of way. I learned-it's that they can say these hateful things to each other and-one of the reasons why it is just, like, just really reactionary and not thought out is that kids at that age- the 
$5^{\text {th }}$ grade age-they have very short memories. They'll be in fight with somebody in the morning and then in the afternoon they'll be like sharing, you know, colored pencils or looking at a book together. So that, in a way, is really-and they don't hold it against me. (Laughs) Like, when l've had confrontations with kids they are very, like, quick to get over it. Which I appreciate about that age, but then theywhat kind of irritates me is that they will do something disrespectful in the morning, or like, a half hour ago, and then, like, a little bit later they will be asking me about things (Laughs) and then, l'll be like "You know, just a few minutes ago, you know, you didn't sit down when I asked you to sit down and now you want a favor from me." That was like a theme in my classroom. "If you don't do good things for me then I can't do good things for you."

INTERVIEWER: What did you do for them?

INDIANA: Just like, well, for instance, one of my ways of getting them to line up or rally in the hall after lunch and be quiet would be to-I always had a bottle of hand sanitizer. And they love hand sanitizer. (Laughs) So, I say, "Well, I can't give this to you unless you are in line and quiet." I bought that all year. One of our bathrooms - the sink didn't work so they were not washing their hands all the time but they really wanted to be clean. They wanted to be clean going into lunch and coming out of lunch. Actually, a lot of my classroom management is based on doing good behavior. 'Cause in the beginning I was so focused on what they were doing wrong and it was exhausting. So, at about Thanksgiving time, I started focusing on the positives and I would give points to kids who would open up their grammar books right away when I said "Take out your grammar books." At the end of every week - I had a big crateful of just prizes and junk and then they got to pick-whoever had the most points. Anything from like little activity books to candy, toys-like little racecars and trinkets and things. That reallythat really—it-it-it helped and I'm gonna-l'm gonna do that right way this year. Just to get them in good habits. Another thing I learned is that even though some of these kids want to talk and act like adults, when I would bring up the toys I would be reminded that they are just kids. 'Cause they would get really excited about, you know, the racecars and cute little things to put in their hair. It is still kind of-it's too bad that I had to resort to that because when I was growing up I don't really remember wasting anytime waiting for kids to take out their books. So, I'm not sure - that is how they are reacting to me? Or, you know, personal motivation? Because, I mean, some kids are always going to be right there with you and some kids are just nnn--not always right there with you. You know? I don't-who knows what their mind's on? They may have gotten no sleep the night before or didn't make it on school time to go to for breakfast in the morning. I only learned very few of the stories from my students but I think that if I knew everything that goes on in their lives I would be, like, horrified, because the stories I did know were horrifying. And I only know, like, probably like $10 \%$ of what was going on. 
INTERVIEWER: Could you—could you talk me about that? You don't have to.

INDIANA: Like specific stories? In early spring or winter there was a bunch of kids-it must of been spring because it was warm out. And it was after school. A bunch of kids were playing outside and this man was like doing something in the trunk of his car in an alley and somebody walked up to him. Shot him several times, pushed him in the trunk, and shut the door. And like a bunch of my kids witnessed this.

INTERVIEWER: Oh my gosh.

INDIANA: Yeah, and had to give statements to police the next day and talked about it like it was not out of the ordinary. Also, this spring there was a guy who was walking down the sidewalk in the back of the school and somebody just rode up next to him in a car, shot him, and drove off. And some kids saw that. That was while school was going on. And these are, I mean, to me, these stories are horrifying and that-that's just four things that I know.

\section{4 second pause;}

INTERVIEWER: When your-when your kids witnessed the crime did they-did you do anything in your class about it?

INDIANA: You know, I only kind of found out about it the next day when the kidOne of our security guards is off duty policeman, so he had found out that this kid saw it happen and just came to the classroom and got him so that he could get a witness statement for him, I guess. I think there was only one or two in my class who saw it. I kind of-I think that I talked about it with—and made the statement, kind of one-on-one, but he just seemed-just nonchalant about it and so I didn't. I'm sure he needed to talk about it and I probably should have asked him

INTERVIEWER (Whispers while Indiana continues to speak): That's okay.

INDIANA: more questions but he just seemed-it was no big deal. I think I was more taken aback by it than he was. And then I just let it go. 
INTERVIEWER: That's fine. Anything else? Or did you (4 second pause) Anything else? Do you just want to go on? (8 second pause. INTERVIEWER reads from interview guide) Can you talk about how stuff you learned from your student teaching either helped or hindered what you were doing in the classroom?

INDIANA: Sure. (Very quickly with emotion in her voice) When I was-I did an untraditional program. I did a Master's in a year and I was a residential teacher in a school in the Eastside called lona Specialty School. Throughout the whole school year we were in a classroom with a mentor teacher. So, there was one mentor and two residents. Three adults to a room and 24 kids. So, basically, it was like, like ideal. More than ideal setting. It was on the North Side where a lot of kids are not doing the same poverty issues as the group that I am working with now. So the kids who were there had parents who really cared about their kid's educations who wanted them to be there. So, in many ways it was an ideal setting and I feel like I learned how good it can be. But, in a lot of ways like I never (4 second pause) I never thought-like it wasn't-we didn't have to deal with a lot of things at the training facility that are real life in most Chicago Public Schools. For instance (4 second pause). Just for instance, you know, like the whole, you know, book thing. Kids taking books out of each other's stuff-and I never thought of that. You know, like having kids curse at you or, you know, challenge you physically or verbally or just the amount of, you know, suspensions and the discipline issues and (5 second pause). Parent, you know, low parent involvement compared to in the training facility. So I mean, it was just-it wasn't-it wasn't (5 second pause). It wasn't probably a good (4 second pause) model for the real - the real classrooms that are out there in the Chicago Public Schools. And we knew that the whole year. We knew that this wasn't a typical school, and we knew what we would be dealing with. But to actually be-go through it. I first thought when I heard kids like cursing at each other and being mean I was like "Oh my God, oh." Like, I take it really personally for a long time and still do to a certain extent because I think it's hard to know when dealing with children in an-especially in classroom management situations like "What? What part of what goes on here is a result of what I am doing or not doing? And what would have happened anyway? You know, what's going to be that way, regardless of whoever is in the classroom?" Because I think that it's both. Like some things you're just not, regardless of who you are, you are not going to be able to keep kids from doing. I mean that, but, you know, like I mean most of the time when the principal was coming down the hall the kids would be like "Oh, Ms. Johnson is coming." And they would be like this. (INDIANA acts like a scared student) But I had kids who were like "She ain't nobody." (Laughs) And "If they were thinking that she ain't nobody then, you know, who am I?" So, I mean, there is really, so that's why I say, you know, I was very reflective on "Okay, this was not a good situation in my classroom. What could I do better? But what? When do I stop beating myself up and just think, like, maybe that would have happened, regardless?" Not as a-not to make it a cop-out but, you know, sometimes, you just, and I am not sure. Like, there is a lot of grey area where 
you just don't know. And I do feel like I learned a lot of what to do and what not to do for next year and that l'll be all the better for it next year. Definitely. But yeah, it is a constant reflecting process for me.

4 second pause as music fades out;

INTERVIEWER: Oh that's fine. My last question-and I might ask you some specific questions-is can you tell me a story about a particular event that illustrates what you believe teaching is all about. Especially, like, positive things.

\section{0 second pause;}

INDIANA: In my opinion, I feel like teaching is less about (6 second pause). I think it's actually less about - I think it's less about $4+4=8$ and more about getting kids to believe in themselves and having esteem in themselves and just giving them-helping them get the confidence to know that they can do it because I know all-all —I didn't—all of the kids this year and have ever worked with are so capable. I mean, I just know all of these kids can learn. It's just getting them to a point where they can believe in themselves and can actually do it.

Music up, very softly; Pärt "Fratres, (for string quartet)";

INDIANA: I think the times when I felt I was being most effective as a teacher was the times when I, you know, met with kids before or after school or took the time to just take a kid aside and-and, you know, give them a compliment that hopefully got them through the day. Or, like with my little writer, just encouraging him to keep on writing because I'm not sure that anyone has ever told him he's done-did something good before. Like I just—I don't know-you—if the kids ever hear anything positive. What I think more than anything-What these kids need is for them to know that someone cares about them. And so, that's-that's sort of what I believe it's all about.

INTERVIEWER: Any more successes?

INDIANA: HHUH MMM (7 second pause). Like as far as the kids' successes or my successes?

INTERVIEWER: Any one. 


\section{6 second pause;}

INDIANA: I feel like (6 second pause). It would start in a way we got really good at. I mean, there was just basic things that we did every day that I felt were really good. We would daily oral language where they would fix two sentences that I would put on the board and somebody would come up to the front and fix the sentence. And then they would-if somebody saw something that they didn't see they would raise their hand and help them out. And then after that we would do a journal entry everyday where I would just throw out-What I would do was talk about a story. Like if the journal entry was "Who was special in your life and why?'” I would give my example and we would have a little discussion about it. And then I would give my journal entry of the day and then from there we would move into independent reading. And so, that block of time, that first hour of time in the morning, we got really good at. And I felt that was-that was-that was a success for me. I feel like real confident in that schedule and how I worked it. And in our writing journals everyday - every other day I would respond to what they had written. I loved reading what they had wrote. And they love writing. That - that give-and-take. And it was-always-it's always been easier for me to write my feelings than to say them. And then, yesterday on the last day of school, I had a parent come up and one of her-her child had brought home the journal (Laughs) and she said "I had never seen a teacher write back to them that much. And that really just warms my heart that you wrote to them everyday. And that was just so wonderful." So, for her to say thank you to me was like "Wow." That, that I felt really good about that. I had another parent who sent me a card just thanking me too. And teaching, in a lot of ways, is a thankless job. And I had a lot of kids run out of the school yesterday and not even look back at me (Laughs). So for me to get those two thanks from the parents was-was good. So, those are the little small successes that...

INTERVIEWER: Big successes.

INDIANA (Laughs): You know, you have to like take what you can get and, you know, be thankful for that little stuff because it's hard.

Music fades out;

INTERVIEWER: Okay, what time do you have?

INDIANA: 11:40. 
INTERVIEWER: Good, we can do this. Let me get another tape.

About a 15 second pause as THE INTERVIEWER opens the cellophane wrapper of new tape and puts it into the cassette recorder.

INTERVIEWER: I have some other questions.

Music up; Pärt, "Fratres (for cello and piano)";

INDIANA: Yeah, go ahead.

INTERVIEWER: Why don't you talk about your after-what you did after-school. Because you said you would sometimes have the kids come after-school, before school and work with them?

INDIANA: I-school starts at 7:50 for us and I was there at 7 o'clock everyday. So if the kids had questions with their homework or didn't understand something that we had gone through the day before they always knew they could come up in the morning at 7 . (4 second pause) I had a little-sort of like a little math club in the winter that would meet. Morning Math, I called it. And we would work on basic things. But it was, you know, it was the kids who really cared enough to be there anyway. And, you know, most of those kids didn't—probably didn't need as much help as some of the kids who should have been there so in some ways it ended up being like a time to challenge some of the kids a little bit more. And then, they always knew they could stay after school too for help on whatever. Yeah, we were a 7:30 to 1:30 school so, you know, at 1:30 the class is dismissed and a lot of the kids are going home to empty houses or they going home to situations where they didn't even want to go home. I had one girl who towards the end of the year was staying a lot. And she just wanted to stay, I think, for the companionship and I think because she didn't want to go home. So, she would do anything to stay, you know, you know "Can I help you? Can I wash the board? Can I do this and this?" And (5 second pause). She started off the year being real-a lot more outspoken and confrontational but by the end of the year she really mellowed down. About halfway through the year I got a notice that she was to have no contact with her father but never was told why. And she-and she got a lot quieter as the school year went on and actually lost some weight too and so I asked her a couple of times if there was anything she wanted to talk about and she didn't. I was in the contact with the mom and the mom didn't say anything to me or seem like there was any problems and I didn't really-I didn't really press it. I took her home a couple of weeks ago because she stayed late with me and had lost her bus card. She was actually out of the neighborhood so I don't know how she was going to the school but I took her home and then I saw why she wasn't really anxious to go home. I think those kinds of experiences are good for 
teachers because it really puts in perspective what the kids are-are coming from.

INTERVIEWER: What did you see?

INDIANA: Just, you know, just the projects. I mean it just didn't look very inviting at all. Especially for, you know, for a 10-year-old girl. It looked dangerous but I knew that her grandma was inside because I just talked to her grandma. And just to let your imagination go and to think about what-what might be going on or what these kids have to, you know "Uueewwhh." And in the stair-like I just imagined her like walking up to her place in the stairway and there just seemed like a lot of guys around and I don't know. But it's good, you know, you learned something. For me staying in the winter like I would when I would be going home at 5 o'clock and it was dark-just driving home through the neighborhood after dark was good for me to just remember or just to be seeing what these kids see. Because I wouldn't, you know, if you leave during the day at like 3 o'clock in the afternoon it's a little bit different, but at night when you drive through the neighborhood it's like "Wow."

INTERVIEWER: Where was your school located?

INDIANA: At Pike and Salmon, which is a very interesting area because it is located near University but the other side is-is pretty different. It's not by any means horrible, and I never felt unsafe but, you know, I'm not living there everyday. I don't see everything that goes down like they do.

6 second pause.

INTERVIEWER: Let's see (Looks over his notes; 10 second pause). I guess that's okay (4 second pause). We got to move. We got to break, anyway. Is there anything else you want to say? (3 second pause) Anything else? (4 second pause) And, um, let's just stop.

THE INTERVIEWER turns off the tape recorder. The two talk silently for a moment, and then INDIANA gets up and leaves.

The music continues. THE INTERVIEWER sits quietly and then turns the tape recorder back on and talks silently about the interview. At the conclusion of the reflection, THE INTERVIEWER turns the cassette recorder off and breathes deeply before collecting the cassette tapes and other equipment and putting them into the interview bag. THE INTERVIEWER then gathers the interview 
guides and other papers and puts them into a plastic folder and puts everything in a backpack. THE INTERVIEWER then walks off stage and sits down in the audience.

THE MUSICIANS continue playing until the natural end of the piece.

Applause for INDIANA, THE INTERVIEWER, THE MUSICIANS.

Following the performance there is a post show discussion. ${ }^{7}$

\section{Afterword}

Listening to the Silences is an ethnodrama about remembering the classroom. The piece uses words and music to challenge the audience to understand the stories of Indiana Ingleside, a beginning teacher in the Chicago Public Schools (CPS), at a time when the words of researchers, policy makers, and pundits dominate the public discourse on teaching in urban schools.

Listening to the Silences asks performers and audience members to engage with the remembered experience of a single urban educator. We are asked to feel the moments of connection that inspired Indiana's work, and to connect to the pain and hardship that made it difficult for her to carry on. The script dramatizes an urban classroom that the teacher, herself, believed should have been staffed by a more skilled educator. The ethnodrama describes her efforts to do her best; even when she believed her best was not good enough.

The show evokes Indiana's experience, but it does not provide solutions to the problems she narrates. The audience cannot stop the performance and shout suggestions to make things better. Building from Dewey (1934) and Siegesmund (2014), the arts are used to erase the web of talk that shapes preconceived notions of classroom life and to bring form to individual experience. Listening to the Silences asks the audience to hear what is spoken and to imagine moments that are not voiced.

The research. I first interviewed the research participant upon whom the character of Indiana Ingelside is based (hereafter referred to by the first name of that pseudonym) for a larger research study in the offices of the Chicago

\footnotetext{
${ }^{7}$ In inquiry theatre productions, what the audience says in response to the drama is as important as the show itself. See the last section of the Afterword, below, for a discussion of this part of the performance.
} 
Teacher's Union on Wednesday, June 23rd, just days after the end of the $2003 / 2004$ school year. This session was the first of four interviews in which the beginning teacher participated as part of this project. Similar to the other teachers in the study, Indiana was paid for her time and received the interview guide and justification for the study in advance (see Vanover, 2014c for these materials).

I designed the original study to surface positive memories of the classroom, and hoped to use the stories I collected to describe the worlds teachers created in their work with children (see discussions in Vanover, 2013a, in press). I recruited a group of five beginning teachers, including Indiana, and a group of experienced teachers who had been certified as accomplished teachers by a nationally respected assessment. All teachers were asked to tell stories about the students for whom they made a difference, and all were asked to describe lessons of which they were proud. The interviews were organized around techniques described in Weiss (1995), and once the teachers had shared their initial responses to the interview guide, I asked each of them, including Indiana, to expand on their stories, to fill in details of the events they shared.

Background to the script. The CPS elementary school described in Listening to the Silences was located in a neighborhood with a high concentration of families living in poverty. Acts of violence frequently disturbed the life of that community, and conflict added to the challenges that confronted local families. In Indiana's account, these social forces did not remain outside the walls of her school building, but shaped the life of the beginning teacher's classroom in ways she found difficult to manage. Indiana's narrative is a unique product of her experiences, but the struggles Indiana described were not unique to her classroom or to her school. Research on CPS shows, at that time in the school system's history, many schools in Chicago's most beleaguered neighborhoods operated without essential social supports, and, in these schools, the system delivered a bitter set of challenges to the professionals who chose to serve the city's most vulnerable students (Allensworth, Ponisciak, \& Mazzeo, 2009; Sebring, Allensworth, Bryk, Easton, \& Luppescu, 2006).

I believe some of the most powerful moments in Listening to the Silences are Indiana's reflections on her responsibility for the events that occurred during her first year as a classroom teacher. From one perspective, it was Indiana's job to provide for the educational development and welfare of the students in her care. Following the "no excuses" ethos espoused by the administrators of many high poverty schools, the successes of Indiana's students were the beginning teacher's successes; her students' failures were her failures. The ability to alter students' academic trajectories is assumed to be within the beginning teacher's span of control, and the events that occurred within her classroom are viewed as a reflection of the beginning teacher's knowledge and will. From another perspective, it is unlikely that a single beginning teacher will pay what LadsonBillings (2006) describes as the debt society owes children of color and make up 
for the years of social injustice and institutionalized racism that continues to shape life in the United States.

Why ethnodrama? As Barone (2001) and Donmoyer and Donmoyer (1995) emphasize, a major justification for using arts based methods to study a particular area of social life is the arts' usefulness for investigating ambiguous cases and their capacity for bringing this content to the attention of the public at large. Denzin (1997) and Saldaña (2005) emphasize ethnodrama is the premier artistic form for bringing the passion and conflict of events in the field into a public research setting. The arts may be used to create empathetic awareness and evoke the experience of members of marginalized groups (Finley, 2011; Leavy, 2015).

Successful ethnodramatic performance works by compressing events and by removing extraneous detail (Saldaña, 2011). To transform data into art, and to create a dramatic production out of interviews, fieldnotes, and other content, researchers must get to know their data (Feldman, 1994, 2005). They must see what is alive in the materials they have collected and have the skill to fashion that content into forms that succeed artistically (Barone \& Eisner, 2011; Chilton \& Leavy, 2014; Goldstein, 2012).

Listening to the Silences uses words and music to create a meditative vehicle. Indiana's inarticulateness, her struggles with language, and the beginning teacher's honesty about her challenges are staged to push the audience out of stale habits of mind. In Eisner's (2007) words, "What we seek [e.g. through ethnodrama] are new ways with which to perceive and interpret the world, ways that make vivid realities that would otherwise go unknown" (p. 10).

Listening to the Silences is an organic product of a series of research events. The script emerged by chance, rather than conscious design. It took many years for me to learn to see Indiana's interviews clearly enough to envision this performance event.

Shaping the script. Listening to the Silences was constructed using the same inquiry theatre techniques I used to dramatize the narratives of other teachers I interviewed for this larger research project (see Vanover, 2016). Long before I decided to create Indiana's ethnodrama, I had transcribed the first interview verbatim and had her three subsequent interviews professionally transcribed. As part of the work I did for the original research study, I checked each of those transcripts for accuracy and removed identifying details. I then coded this material many times in response to a changing set of research questions, and this labor allowed me to get to know the beginning teacher's story in depth. At first, I did not understand how to communicate what I had learned from my attempts to interpret that content. It took me many years to bring the project into form and dramatize the data. 
When I decided to construct a play from Indiana's interviews, I began by selecting material I believed best communicated the beginning teacher's personal story. During this initial coding process (Saldaña, 2012), I looked for moments when the dialogue between Indiana and the interviewer communicated honest emotion. I searched for moments that mattered, given my understanding of life in the Chicago schools. I deleted all other content.

The playscript emerged through these repeated efforts to engage and erase the data. It was difficult for me to make cuts, and for the first drafts I hung onto many different selections from Indiana's narrative in the hope they might somehow find a way into the show. From the text I coded, I had about two hours of dialogue, and I felt every word Indiana had spoken was essential. A critical moment occurred after I put the work aside for a couple of days, and then again looked over what I had coded. As I re-read the first couple of pages, I saw the outline of a sparse and modest performance. When I transcribed Indiana's first interview I had timed each major pause in that session and I had noted the lengths of each of those silences in the transcript. During earlier stages of the research study, I had read that content at least a hundred times, but, until that moment, I had not seen how those pauses might communicate dramatically. I realized I might create an ethnodrama from the beginning teacher's silences. I cut all the material from Indiana's second, third, and fourth interviews from this new version of the script.

Over the next days, I moved back and forth over what remained from the first interview and imagined how that material might come to life. Sometimes I would cut a piece of text and then put it back into the script when I had a better understanding of how the different elements of Indiana's story weaved together. Mostly, I erased. The words spoken in Listening to the Silences are the words that remained after I cut two thirds of the stories Indiana voiced in her first interview.

The last cuts were difficult. I had deleted everything from the first interview except the sections that mattered most to me, and the piece was still too long. Inquiry theatre performances work best when the play lasts for about 40 minutes; anything longer makes it difficult to find the time to discuss the show in depth. I had written an abstract to perform Listening to the Silences as part of a symposium. The abstract had been accepted and, by that time in the creative process, I had already auditioned two actors-Kisha Barr and Jenna Lam-to perform the show. I sent the script to the performers and asked them to run through it. They told me the show ran for about an hour and ten minutes. This was one of those moments when one must think strictly as an artist (Saldaña, 2011); I cut about 25 minutes of the material from that next-to-last script. I deleted stories that I felt provided critical insight into Indiana's character. I deleted stories that raised important issues about her school. I deleted dialogue that helped connect the different pieces of the script into a coherent storyline. Playing with the data in this manner made the script stronger. I wished for the 
audience to have time to talk about Indiana's experience; I did not wish Indiana's story to get lost in a forest of words.

Listening to the Silences is what I call pure, verbatim theatre. Nothing has been added to the script that was not spoken during the first interview session. Every word and hesitation in the performance are written in the original order in which they were voiced. The script is not the only story that could be told from Indiana's interviews, and what Indiana told me was not the only story she could tell (Denzin, 2001). Listening to the Silences dramatically reduces the content Indiana shared during her interview sessions, but enough material remains to communicate critical information about the beginning teachers' choices. As I wrote in the opening section of the playscript, theatre artists who may consider using the script are welcomed to cut it further depending on the needs of their audiences. I believe the current script works well for teachers and pre-service educators; other audiences may not need to experience Indiana's story with the same level of detail.

Music within the script. Indiana's experience in CPS, as depicted in the ethnodrama, was shaped by a socially reproduced set of practices that have shaped the lives of classroom teachers for more than a hundred years (see Biklen, 1995; Herbst, 1989). I selected music by the Estonian composer, Arvo Pärt, to envelop Indiana's storytelling because I felt the music speaks to the suffering and incomprehensibility of a common experience. It would be possible to dramatize Indiana's narrative in ways that demoralize her work or to use content from her transcripts to communicate the idea that a beginning teacher's best choice might be to act as a conscientious objector, and walk away from the classroom (e.g. Santoro, 2011), but this was not the message I wanted to convey.

Rather than use words to make sense of this common experience, Listening to the Silences asks participants to engage in inquiry by thinking musically. Arrangements of Arvo Pärt's Fratres play as Indiana's interview is dramatized. The music replaces brief lectures and audience discussions that preceded the earlier performances of the other plays I created from the data set (Vanover, 2013b, 2013c, 2014a). I wished to amplify the impact of the pauses that run through the original transcript and bring Indiana's story into being as what Gouzouasis (2006, pp. 30-33) might describe as a "living inquiry." I hoped the musicians' playing might clear away the noise generated by common images of teachers' labor and help performers and help audience members understand the experiences Indiana describes and tune into life (see Carlsen \& Dutton, 2011; Dutton, 2003).

Pärt's music is based on his long study of Gregorian Chant, Plainsong, and other sacred music, and his pieces seek to connect the listener to the divine (McCarthy, 1995). Fratres is intended to communicate a universal experience. In the words of conductor Paul Hillier (1989): 
Arvo Pärt's music accepts silence and death, and thus reaffirms the basic truth of life, its frailty compassionately realized, its sacred beauty observed and celebrated. [Pärt] uses the simplest of means - a single note, a triad, words - and with them creates an intense, vibrant music that stands apart from the world and beckons us to an inner quietness and an inner exaltation. (p. 134)

Indiana was a stranger in a strange land. She had left the world where she grew up and had moved to Chicago to serve the poor. While there were many aspects of her service that were difficult for her to mange, Indiana did not turn away from the path she set. When times became hard, she endured. The ability to act with such determination and strength is deeply valued by African American communities (Collins, 1999; Foster, 1997; Ladson-Billings, 1994). Listening to the Silences attempts to move beyond simple dualisms, such as effective and ineffective, and help audience members understand the worth of suffering and the power of commitment.

Unlike the music for my other ethnodramatic works, such as Chalkboard Concerto (Vanover \& Saldaña, 2005), or Teaching the Power of the Word (Vanover, 2014b), this script makes little effort to set the dialogue between Indiana and The Interviewer to particular moments in the score. During the performance, it is my intension for musicians and actors to respond to the energy of the moment and react to rhythms that develop as Indiana's story unfolds. Sometimes the music might move ahead of the actors, and sometimes it might move behind. Connections between the dialogue and the musicians' playing are intended to arise by chance as much as by artistry. The counterpoint that grows between voice and music raises performers' and audience members' vulnerability. Indiana's experience is presented in a manner that exposes her suffering to the eyes of outsiders and broadcasts her pain to people she had never met.

The final piece of music in the performance, Pärt's Fratres (for cello and piano), begins to play after the formal part of the interview concludes, when Indiana volunteers to answer some follow up questions that had not been written into the interview guide. The Interviewer asks Indiana to discuss her efforts to work with students outside of the regular school day. The beginning teacher describes the afternoon program she created for a couple of her students, and one of the relationships that grew up within that environment. The score is intended to communicate what Indiana leaves unspoken.

The musicians continue to perform Pärt's Fratres (for cello and piano) after Indiana stops speaking, the interview ends, and the actors leave the stage. The same six bar theme that has played throughout the ethnodrama continues to sound. Strings, piano, and percussion speak to the stress, joy, and exhaustion Indiana experienced over her first nine months as a classroom teacher. 
I hope this music encourages audiences to detach from the words they might have previously used to describe teachers' lives and connect to the beauty of the moment in performance. Nora Pärt, Arvo's wife, described the power of such an experience in an interview with the Musical Times:

By the end the listening attention is utterly focused. At the point after the music has faded away it is particularly remarkable to hear your breath, your heartbeat, the lighting or the air conditioning system. (Smith, 1999, p. 22)

The after-performance dialogue. The dialogue that begins after the ethnodramatic performance ends is integral to the ethnodrama. Listening to the Silences is not intended to linger in audience members' minds as an isolated performance event, but to spark conversation between individuals and to help people discuss questions that matter. As with all my plays that use inquiry theatre methods (see Vanover, 2016), the show is intended to heighten ambiguity and add richness to the experience of commonly understood events. I am not alone in such work. Theatre has been used to support dialogue into social problems in a wide range of cultures and for a wide range of occasions (Favorini, 1995; Finley, 2011; Mitchell \& Freitag, 2011; Prendergast \& Saxton, 2013). Creating such dialogue is one of the core goals of arts-based research practice (Cahnmann-Taylor \& Siegesmund, 2013; Greene, 1977; Leavy, 2015).

Each of the performances of Listening to the Silences provoked strong reactions from audience members. During the talkbacks I facilitated, people told me they identified with Indiana's struggles and felt compassion for her and her students. Audience members wondered if Indiana had recovered from her first year in the classroom, and whether the beginning teacher was able to make use of the things she said she had learned.

The most surprising dialogue generated by the ethnodrama was shared at the first performance at Temple University, Philadelphia. The performers and I put up the show for a group of students at Temple University's College of Education (see the first photo as well as the second series of photos). The students in the audience were pre-service teachers in the city's schools, and, as I expected, Indiana's experiences brought up issues the young people wrestled with as they engaged in the observation hours and other teacher preparation activities required by their degree programs. What I did not expect was that almost all of these students had graduated from urban high schools in Philadelphia. I spent most of the talkback listening as the young people shared stories about their own experiences in the city's schools. Dialogue continued at Temple, as it did for the other performances, past the time we had allotted for the show. 
In the other ethnodramas I wrote using inquiry theatre methods, we used a range of techniques to encourage audience members to discuss the main character's storyline. I believed there was no need to engage in these activities during performances of Listening to the Silences. Beyond sharing Pärt's music, I did not wish to tell people how to think nor what to say. After the performance for the Ethnography in Education Research Forum at the University of Pennsylvania, in Philadelphia, I asked the audience to form into groups to discuss the performance, and then I walked out of the room to let people discuss the show on their own for 15 minutes. When I came back, I sat with the actors and talked with them about the performance, before getting up to facilitate a whole group discussion that continued for about an hour. The show's Co-Chairs and Discussant were dispersed throughout the audience. Dialogue flowed naturally.

My most significant learning from the talkback sessions at the performances was to trust Indiana's commitment and integrity. Originally, I had a more negative outlook towards the beginning teacher and the events she discussed. This perspective softened as I sat in the audience and watched Indiana's story come to life, and then heard the dialogue engendered by her storytelling. One audience member, during the talkback at the University of Pennsylvania Ethnography in Education Research Forum, told me she believed Indiana's storytelling was shaped by her deep commitment and reflection. Indiana's words were so lucid that many of the stories the beginning teacher shared might have been written before they were voiced in the interview, developed during the journaling sessions Indiana described ${ }^{8}$. She said Indiana reminded her of herself during her first year in the classroom.

I hope Listening to Silences communicates the moral commitment that shaped Indiana's labor and helps audiences ponder what it means to learn to teach by teaching in systems that do not reliably provide teachers and students with the support they need to live their dreams.

\footnotetext{
${ }^{8}$ For discussions of teacher learning see Lampert (2010), Rogers (2002), and Sinner (2013).
} 

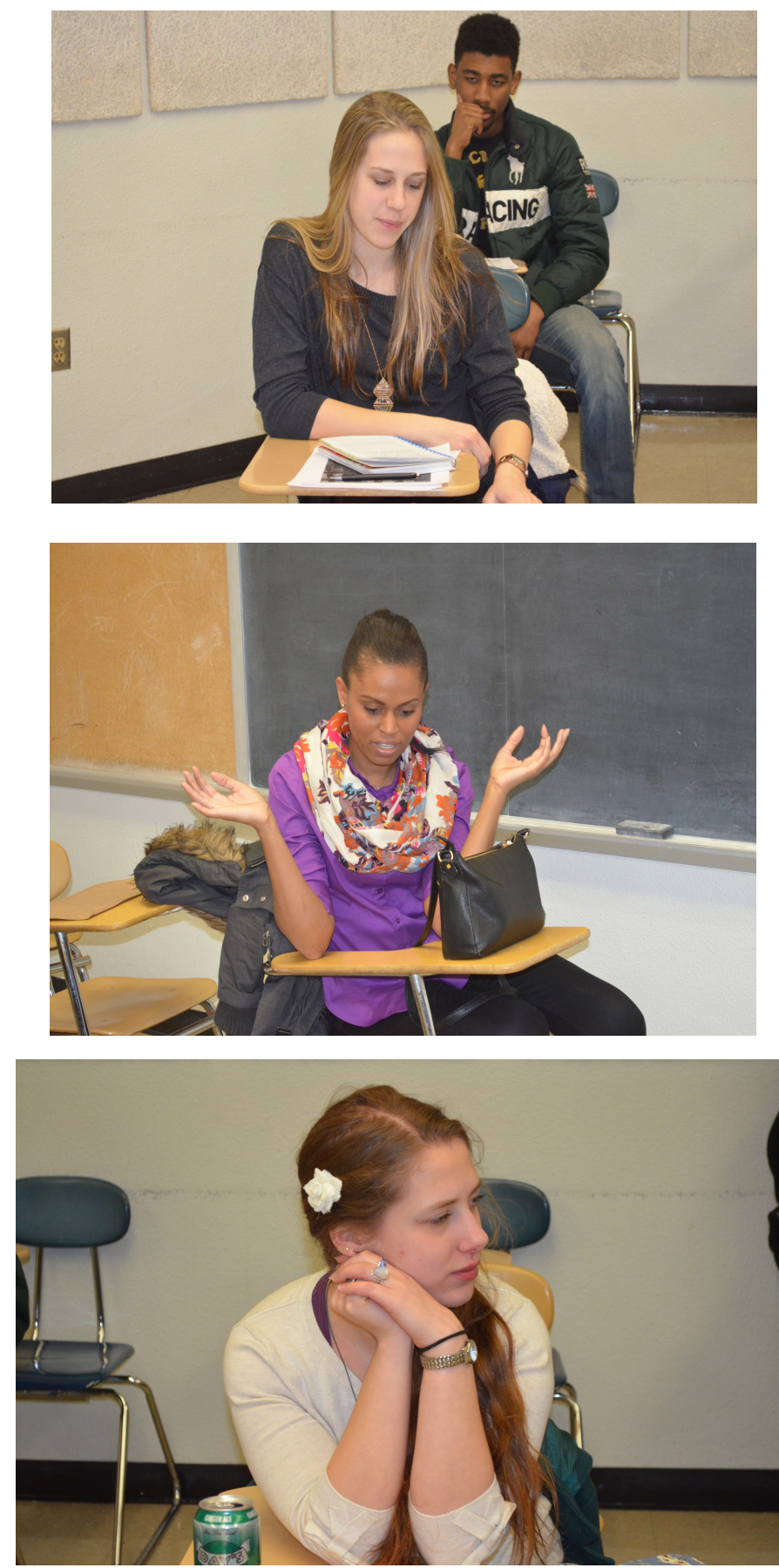

Photos $8,9 \& 10^{9}$ : Audience and actors discussing the play at the conclusion of the Temple University performance. Photo credit: Charles Vanover

\footnotetext{
${ }^{9}$ Photos in this series come from the Temple University College of Education performance.
} 
Acknowledgments: I would like to acknowledge the work of Kisha Barr and Jenna Lam, who played the parts of Indiana Ingleside and The Interviewer at the Philadelphia workshops. I would like to acknowledge the work of Lisa Powers Tricomi and Bob Devin Jones for performing the parts of Indiana and The Interviewer at the performances at Saint Petersburg, Florida's The Studio @ 620. I would like to recognize Nancie Sanderson Byrne for casting support for the Philadelphia shows. No discussion of my work is complete without acknowledging the many years of support I have received from my friends and colleagues who helped facilitate the shows at the Penn Ethnography in Educational Research Forum, especially, Andrew Babson, Sarah Hobson, Alexandra Miletta, Brandi Slider Weekley, and K. Nicola Williams. Finally, I would like to acknowledge the work of the pseudonymous Chicago teacher who spoke to me about her experience with honesty and compassion. 


\section{References}

Allensworth, E., Ponisciak, S., \& Mazzeo, C. (2009). The schools teachers leave: Teacher mobility in the Chicago Public Schools. Consortium on Chicago School Research. [Website]. Retrieved from: http://ccsr.uchicago.edu/publications/schools-teachers-leave-teachermobility-chicago-public-schools

Barone, T. (2001). Science, art, and the predispositions of educational researchers. Educational Researcher, 30(7), 24-28.

Barone, T., \& Eisner, E. W. (2011). Arts based research. Thousand Oaks, CA: Sage.

Biklen, S. K. (1995). School work: Gender and the cultural construction of teaching. New York: Teacher's College Press.

Cahnmann-Taylor, M., \& Siegesmund, R. (2013). Arts-based research in education: Foundations for practice. New York: Routledge.

Carlsen, A., \& Dutton, J. E. (2011). Research alive: The call for generativity. In A.

Carlsen \& J. E. Dutton (Eds.), Research alive: Exploring generative moments in doing qualitative research (pp. 11-24). Copenhagen, DK: Copenhagen Business School Press.

Chilton, G., \& Leavy, P. (2014). Arts-based research practice: Merging social research and the creative arts. In P. Leavy (Ed.), Oxford Handbook of Qualitative Methods (pp. 403-422). New York: Oxford.

Collins, P. H. (1999). Black feminist thought: Knowledge, consciousness, and the politics of empowerment. New York: Routledge.

Denzin, N. K. (1997). Interpretive ethnography: Ethnographic practices for the 21st century. Thousand Oaks, CA: Sage.

Denzin, N. K. (2001). The reflexive interview and a performative social science. Qualitative Research, 1(1), 23-46.

Dewey, J. (1934). Art as experience. New York: Perigee Books.

Donmoyer, R., \& Donmoyer, Y. J. (1995). Data as drama: Reflections on the use of reader's theater as a mode of qualitative data display. Qualitative Inquiry, 1(4), 402-428. 
Dutton, J. (2003). Breathing life into organizational studies. Journal of Management Studies, 12(1), 5-19.

Eisner, E. W. (2007). Art and knowledge. In J. G. Knowles \& A. L. Cole (Eds.), Handbook of the arts in qualitative research: Perspectives, methodologies, examples, and issues (pp. 3-12). Thousand Oaks, CA: Sage Publications.

Favorini, A. (1995). Voicings: Ten plays from the documentary theatre. New York: Ecco Press.

Feldman, M. S. (1994). Strategies for interpreting qualitative data (vol. 33). Thousand Oaks, CA: SAGE.

Feldman, M. S. (2005). Why ethnodrama, and why not?: Keynote address to the University of Michigan Narrative Institute [PowerPoint slides]. USFSP Digital Archive [Website]. Retrieved from: http://hdl.handle.net/10806/6300

Finley, S. (2011). Critical arts-based inquiry. In N. K. Denzin \& Y. S. Lincoln (Eds.), The SAGE Handbook of Qualitative Research ( $4^{\text {th }}$ ed.) (pp. 435450). Los Angles, CA: Sage Publications.

Foster, M. (1997). Black teachers on teaching. New York: The New Press.

Goldstein, T. (2012). Staging Harriet's house: Writing and producing researchinformed theatre. New York: Peter Lang.

Gouzouasis, P. (2006). A/r/t/ography in music research: A reunification of musician, researcher, and teacher. Arts and Learning Journal, 22(1), 2342.

Greene, M. (1977). Toward wide-awakeness: An argument for the arts and humanities in education. The Teachers College Record, 79(1), 119-125.

Herbst, J. (1989). And sadly teach: Teacher education and professionalization in American culture. Madison, Wl: University of Wisconsin Press.

Hillier, P. (1989). Arvo Pärt: Magister Ludi. The Musical Times, 130(1753), 134137.

Ladson-Billings, G. (1994). The dreamkeepers: Successful teachers of African American children. San Francisco, CA: Jossey-Bass.

Ladson-Billings, G. (2006). 2006 presidential address: From the achievement gap to the education debt: Understanding achievement in U.S. schools. Educational Researcher, 35(7), 5-12. 
Lampert, M. (2010). Learning teaching in, from, and for practice: What do we mean? Journal of Teacher Education, 61(1-2), 21-34.

Leavy, P. (2015). Method meets art: Arts-based research practice ( $2^{\text {nd }}$ ed.). New York: The Guilford Press.

McCarthy, J. (1995). An interview with Arvo Pärt. Contemporary Music Review, 12(2), 55-64.

Mitchell, K. S., \& Freitag, J. L. (2011). Forum Theatre for bystanders: A new model for gender violence prevention. Violence Against Women, 17(8), 990-1013.

Part, A. (1977). Fratres [Recorded by Rudolf Werthen \& I Fiamminghi, the Orchestra of Flanders]. On Arvo Part Fratres [CD]. Beverly Hills, CA: Telarc. (First recorded, 1994).

Prendergast, M., \& Saxton, J. (2013). Applied drama: A facilitator's handbook for working in community. Chicago, IL: Intellect Books.

Rogers, C. (2002). Defining reflection: Another look at John Dewey and reflective thinking. Teachers College Record, 104(4), 842-866.

Saldaña, J. (2002). Dramatizing data: A primer. Qualitative Inquiry, 9(2), 218236.

Saldaña, J. (2011). Ethnotheatre: Research from page to stage. Walnut Creek, CA: Left Coast.

Saldaña, J. (2012). The coding manual for qualitative researchers. Thousand Oaks, CA: Sage.

Saldaña, J. (Ed.). (2005). Ethnodrama: An anthology of reality theatre. Walnut Creek, CA: AltaMira.

Santoro, D. A. (2011). Teaching's conscientious objectors: Principled leavers of high-poverty schools. Teachers College Record, 113(12), 26-70.

Sebring, P. B., Allensworth, E., Bryk, A. S., Easton, J. Q., \& Luppescu, S. (2006). The essential supports for school improvement. Consortium on Chicago School Research [Website]. Retrieved from: https://ccsr.uchicago.edu/publications/essential-supports-schoolimprovement 
Siegesmund, R. (2014). The N of 1 in arts-based research: Reliability and validity. International Journal of Education \& the Arts, 15(SI 2.5) [Online]. Retrieved from: http://www.ijea.org/v15si2/v15si2-5.pdf

Sinner, A. (2013). Unfolding the unexpectedness of uncertainty: Creative nonfiction and the lives of becoming teachers. Rotterdam, NL: Springer Science \& Business Media.

Smith, G. (1999). An interview with Arvo Pärt: Sources of invention. The Musical Times, 140(1868), 19-25.

Vanover, C. (2013a). Making time for failure. USFSP Digital Archive [Website]. Retrieved from: http://hdl.handle.net/10806/6252

Vanover, C. (2013b). "They are only going to steal your cars." USFSP Digital Archive [Website]. Retrieved from: http://hdl.handle.net/10806/12345

Vanover, C. (2013c). What does it mean to work in a system that fails you and your kids?: A beginning teacher's journey through the Chicago Public Schools. USFSP Digital Archive [Website]. Retrieved from: http://hdl.handle.net/10806/6251

Vanover, C. (2014a) Goodbye to All That!: An accomplished teacher's last year in the Chicago Public Schools. USFSP Digital Archive [Website]. Retrieved from: http://hdl.handle.net/10806/11932

Vanover, C. (2014b). Teaching the power of the word. International Journal of Qualitative Studies in Education. 27(7), 922-942.

Vanover, C. (2014c). The Expertise in Urban Teaching Project: Interview instruments, recruitment letters, and other materials. USFSP Digital Archive [Website]. Retrieved from: http://hdl.handle.net/10806/12366

Vanover, C. (in press). From connection to distance: Using the practice of artsbased research to interpret fieldwork. The Journal of Contemporary Ethnography.

Vanover, C. (2016). Inquiry theatre. Qualitative Inquiry, 22(4), 238-248.

Vanover, C., \& Saldaña, J. (2005). Chalkboard concerto: Growing up as a teacher in the Chicago Public Schools. In J. Saldaña (Ed.), Ethnodrama: An anthology of reality theatre (pp. 62-77). Walnut Creek, CA: AltaMira Press. Retrieved from: http://hdl.handle.net/10806/6222

Weiss, R. S. (1995). Learning from strangers: The art and method of qualitative interview studies. New York: Free Press. 
Young Musicians Foundation. (2010). Fratres by Arvo Pärt [Video]. Retrieved from: https://www.youtube.com/watch?v=DL4wHdalOyc 